\title{
HUBUNGAN IMT DENGAN KELINCAHAN MENGGIRING BOLA PADA SISWA PUTERA EKSTRAKULIKULER SEPAK BOLA SISWA SMAN 1 AIKMEL TAHUN 2017
}

\author{
Baihaqi Annas ${ }^{1}$, Karno Dinata ${ }^{2}$, Didik Daniyantara ${ }^{3}$ \\ email: baihaqiannas75@gmail.com ${ }^{1}$, karnodinata111@gmail.com ${ }_{2}^{2}$ daniyantara_didik@yahoo.com ${ }^{3}$ \\ MI Al-Hasani Ma'rif Karang Baru ${ }^{1}$, Program Studi Pendidikan Jasmani Kesehatan dan Rekreasi, \\ Fakultas Ilmu Pendidikan, Universitas Hamzanwadi ${ }^{2,3}$
}

\begin{abstract}
Abstrk
Penelitian ini bertujuan untuk mengetahui ada atau tdak ada hubungan IMT dengan kelincahan menggiring bola pada siswa putra ekstra kulikuler sepak bola siswa SMAN 1 Aikmel tahun 2017. Jenis penelitian ini menggunakan metode eksperimen. Populasi sampel seluruh siswa yang mengikuti ksrakulikuler sepakbola SMAN 1 Aikmel tahun 2017 yang berjumlah 25 siswa. Teknik pengumpulan data menggunakan tes perbuatan dan dokumentasi. Sedangkan teknik analisis data menggunakan rumus product moment. Berdasarkan hasil analisis data diperoleh nilai $\mathrm{r}$ hitung sebesar 3.801 sedangkan nilai $\mathrm{r}$ tabel dengan taraf signifikan 5 $\%$ menunjukkan angka sebesar 0.396, hal ini $\mathrm{r}$ hitung yang diperoleh lebih besar dari angka batas penolakan hipotesis nihil (Ho) dari hasil analisis data diatas, maka dapat dsimpulkan bahwa: ada hubungan IMT dengan kelincahan menggiring bola pada siswa putera ekstrakulikuler sepak bola siswa SMAN 1 Aikmel tahun 2017

Kata kunci: Indek Masa Tubuh (IMT), Menggiring Bola
\end{abstract}

\begin{abstract}
Abstrat
This study aims to determine whether or not there is an IMT relationship with agility dribbled on students' extra-curricular students football SMAN 1 Aikmel in 2017. This type of research using experimental methods. The sample population of all students who follow football exrakulikuler SMAN 1 Aikmel year 2017 which amounted to 25 students. Data collection techniques use action and documentation tests. While the technique of data analysis using product moment formula. Based on the results of data analysis obtained value of $r$ counted 3.801 while the value of $r$ table with a significant level of $5 \%$ indicates the number of 0.396 , it is $\mathrm{r}$ calculated obtained greater than the limit number of rejection of null hypothesis (Ho) From the results of data analysis above, it can be concluded that: There is an IMT relationship with agility dribbling on students' extra-curricular students football students SMAN 1 Aikmel in 2017.
\end{abstract}

Keywords: Body Performance Index, Dribbling Ball

\section{A. Pendahuluan}

Cabang olahraga sepak bola sangat populer di kalangan masyarakat, hal ini dapat dilihat dengan banyaknya masyarakat baik pria maupun wanita yang ke lapangan sepak bola. Kedatangan masyarakat tersebut menggambarkan betapa besarnya animo masyarakat terhadap 
cabang olahraga sepak bola, walaupun masing- masing memiliki alasan yang sekedar mengisi waktu luang, meningkatkan keterampilan bahkan ada yang hanya ingin menonton permainan sepak bola tersebut. Namun dari pada itu untuk meningkatkan keterampilan bermain sepak bola, itu merupakan suatu hal yang tidak mudah untuk didapat dan dikuasai, jika tidak melalui proses berlatih melatih dan dibimbing oleh seorang pelatih. Ada beberapa faktor kesuksesan seorang pemain di dalam usahanya untuk menjadi seorang pemain sepak bola yang terampil. Salah satunya adalah faktor genetic mengenai perwarisan genes dari satu generasi ke generasi berikutnya mengajarkan bahwa kemampuan fisik dan postur tubuh seseorang banyak dipengaruhi oleh warisan genes dari orangtuanya (Salim,2008:18). Dengan demikian postur tubuh yang kelewat kecil ataupun besar dapat berpengaruh buruk terhadap keterampilan seseorang bermain bola. Apabila seseorang berpostur sangat kecil, maka ia akan mudah untuk dijatuhkan, mengalami kesulitan dalam menjangkau bola-bola atas, dan sebagainya. Di lain pihak, apabila pemain terlalu tinggi maka ia akan kesulitan bergerak dengan lincah, sulit menguasai teknik individu (Salim,2008:17). Kemampuan fisik dan postur tubuh setiap orang berbeda-beda. Hal ini disebabkan oleh genetika. Perbedaan tersebut dalam dunia sepak bola sangat mempengaruhinya. Apabila seorang pemain berpostur tubuh kecil maka ia akan mudah untuk lawan mainnya. Selain itu, kecepatan dalam berlari pun tidak menutup kemungkinan lambat jika dibandingkan dengan pemain yang berpostur tubuh tinggi. Begitu juga sebaliknya, pemain sepak bola yang memiliki ukuran tubuh terlalu besar akan memiliki kesulitan dan hambatan tersendiri dalam bermain sepak bola hal ini menunjukan bahwa gizi dan olah raga secara bersama-sama akan menghasilkan prestasi yang baik. Dengan memperhatikan gizi dalam berolah raga baik sebelum dan sesudah latihan dapat membantu atlet mencapai performa terbaik mereka (WHO,2007:22). Setiap cabang olah raga punya kebutuhan gizi yang berbeda, akan tetapi secara umum telah diakui bahwa energi dan cairan merupakan 2 (dua) zat gizi yang perlu diprioritaskan, oleh karena itu harus tercukupi kebutuhannya (WHO,2007:22). Indeks masa tubuh adalah rasio standar berat terhadap tinggi, dan sering digunakan sebagai indikator kesehatan umum. Bentuk tubuh pemain sepak bola harus ideal yaitu, sehat, kuat, tinggi dan tangkas (Mielke, 2007: 11). Seorang pemain sepak bola harus mempunyai IMT yang normal dengan Tinggi Badan (TB) diatas ratarata. Komposisi tubuh harus proporsional antara massa otot dan lemak. Standar ideal untuk ukuran anak SMA laki-laki yang umur 15 tahun itu 16.1-26.9 kg, sedangkan untuk perempuan 16.0-28.1 kg, kemudian untuk umur 16 tahun standar idealnya 16.6-27,8 kg, sedangkan anak perempuan 16.3-28.3 kg (WHO,2007:16). IMT adalah cara termudah untuk memperkirakan obesitas serta berkorelasi tinggi dengan massa lemak tubuh, selain itu juga penting untuk mengidentifikasi pasien obesitas yang mempunyai risiko mendapat komplikasi medis. (WHO, 2007:21). IMT merupakan petunjuk untuk menentukan kelebihan berat badan berdasarkan Indeks Quatelet berat badan dalam kilogram dibagi dengan kuadrat tinggi badan dalam meter $(\mathrm{kg} / \mathrm{m} 2)$ Salah satu teknik dasar yang belum maksimal dikuasai oleh pemain adalah teknik menggiring bola khususnya para pemain SMAN 1 Aikmel. Hal ini terlihat dalam, latihan, permainan maupun dalam pertandingan, para pemain banyak kehilangan bola, karena bola yang diterima tidak sepenuhnya dikuasai oleh pemain tersebut. Bola yang sebenarnya dapat digiring agar lebih dekat ke sasaran, karena tidak memiliki keterampilan menggiring bola, karena bola tersebut secara tergesa- gesa langsung di tendang ke teman sehingga bola direbut dapat dikuasai oleh lawan. Menurut (Mielke,2007:1): "Ketika mulai mempersiapkan diri 
untuk bertanding, keterampilan utama yang pertama kali akan membuatmu terpacu dan merasa puas adalah kemampuan menggiring bola (dribbling)". SMAN 1 Aikmel adalah salah satu sekolah yang mempunyai pemain sepakbola rata-rata dibawah 18 tahun. SMAN 1 Aikmel memiliki prestasi yang bagus di Kabupaten Lombok Timur salah satunya dalam olahraga sepakbola. Untuk mempertahankan dan meningkatkan prestasi tersebut perlu pembinaan atlet melalui latihan yang terstruktur dengan baik, dan menjaga berat badanya (IMT) untuk mengimbangi badannya waktu latihan dan bertanding. Salah satu teknik dalam sepakbola yang perlu ditingkatkan adalah tingkat akurasi menggiring bola (dribbling). Berdasarkan hasil observasi yang telah peneliti lakukan pada gelaran LPI (Liga Pelajar Indonesia) kabupaten Lombok Timur awal tahun 2017 ditemukan bahwa pemain SMAN 1 Aikmel melakukan banyak kesalahan terutama dalam menggiring bola, dan secara umum tingkat penguasaan individu pemain masih lamban. Ini besar kemungkinan di akibatkan oleh berat badan yang berlebih. Berdasarkan latar belakang tersebut diatas, maka peneliti terdorong untuk melakukan penelitian tentang "Hubungan indek masa tubuh dengan kelincahan menggiring bola pada siswa putra ekstrakulikuler sepak bola SMAN 1 Aikmel tahun 2017.

\section{B. Metode}

Jenis penelitian ini adalah jenis penelitian kuantitatif dengan menggunakan metode ekperiment. Metode penelitian ini yang akan digunakan untuk mencari pengaruh perlakuan tertentu terhadap yang lain dalam kondisi yang terkendali" (Sugiyono,2010). Jadi segala yang diteliti dalam penelitian ini dilakukan dengan sengaja. Rancangan penelitian ini adalah suatu pendekatan yang digunakan dalam suatu penelitian. Dalam buku metode penelitian dijelaskan bahwa: rancangan pada dasarnya merupakan keseluruhan proses pemikiran dan menentu matang tentang hal- hal yang dilakukan serta dapat pula dijadikan pula dasar penilaian baik oleh peneliti itu sendiri maupun orang lain terhadap penelitian, dan bertujuan memberi pertanggung jawaban terhadap semua langkah yang diambil (Sugiyono, 2008:107). Untuk mendapatkan data yang diperlukan dibutuhkan instrument. Yang dimaksud dengan instrument penelitian adalah suatu alat yang digunakan mengukur penomena ini disebut variabel penelitian (Sugiyono, 2010). Oleh karena itu peneliti menggunakan instrument yang validitasnya sudah diakui oleh para ahli dibidang ilmu yang bersangkutan. Di samping itu instrument harus disusun sedemikian rupa agar dapat merekam data yang dimaksud. Dalam hal ini peneliti menggunakan alat ukur tes dribbling dalam permainan sepak bola.

\section{Hasil dan Pembahasan}

Pengujian hipotesis dilakukan untuk mengetahui penerimaan atau penolakan hipotesis yang diajukan, uji hipotesis menggunakan uji-t pada taraf signifikan 0,05\%. Hasil uji hipotesis (uji-r) dapat dilihat di bawah ini.

Tabel 1. Tabel Kerja Untuk Mencari $\mathbf{r}_{X y}$

\begin{tabular}{llccccc}
\hline $\mathbf{N}$ & Nama & $\mathbf{X}$ & $\mathbf{Y}$ & $\mathbf{x}$ & $\mathbf{y}$ & $\mathbf{x}$ \\
\hline $\mathbf{1}$ & A Z R & 19. & 12.1 & 366.33 & 146.41 & $\mathbf{2 3 1 . 5 9}$ \\
$\mathbf{2}$ & A R F & 15. & 12.1 & 237.46 & 146.89 & $\mathbf{1 8 6 . 7 6}$ \\
$\mathbf{3}$ & Z A & 14. & 12.3 & 221.41 & 151.78 & $\mathbf{1 8 3 . 3 2}$
\end{tabular}




\begin{tabular}{lllllll}
$\mathbf{4}$ & M. A Z & 15. & 12.1 & 249.95 & 148.35 & $\mathbf{1 9 2 . 5 6}$ \\
$\mathbf{5}$ & I A P & 17. & 11.3 & 293.77 & 128.14 & $\mathbf{1 9 4 . 0 2}$ \\
$\mathbf{6}$ & A Z A & 22. & 12.1 & 493.72 & 146.41 & $\mathbf{2 6 8 . 8 6}$ \\
$\mathbf{7}$ & M M & 17. & 12.1 & 293.77 & 146.41 & $\mathbf{2 0 7 . 3 9}$ \\
$\mathbf{8}$ & Z S & 14. & 12.1 & 221.41 & 146.89 & $\mathbf{1 8 0 . 3 4}$ \\
$\mathbf{9}$ & M S R & 17. & 12.4 & 301.02 & 154.50 & $\mathbf{2 1 5 . 6 6}$ \\
$\mathbf{1 0}$ & SH & 17. & 12.1 & 301.02 & 148.10 & $\mathbf{2 1 1 . 1 4}$ \\
$\mathbf{1 1}$ & S Z & 17. & 12.1 & 293.77 & 148.10 & $\mathbf{2 0 8 . 5 9}$ \\
$\mathbf{1 2}$ & I Z & 17. & 12.1 & 293.09 & 147.13 & $\mathbf{2 0 7 . 6 6}$ \\
$\mathbf{1 3}$ & L. A J & 22. & 12.4 & 528.08 & 153.76 & $\mathbf{2 8 4 . 9 5}$ \\
$\mathbf{1 4}$ & B P & 16. & 11.3 & 263.08 & 127.69 & $\mathbf{1 8 3 . 2 8}$ \\
$\mathbf{1 5}$ & K A & 16. & 11.3 & 263.08 & 127.69 & $\mathbf{1 8 3 . 2 8}$ \\
$\mathbf{1 6}$ & R S & 22. & 11.1 & 528.08 & 123.65 & $\mathbf{2 5 5 . 5 3}$ \\
$\mathbf{1 7}$ & A A & 15. & 11.4 & 237.46 & 131.10 & $\mathbf{1 7 6 . 4 4}$ \\
$\mathbf{1 8}$ & K H & 15. & 12.1 & 249.95 & 146.41 & $\mathbf{1 9 1 . 3 0}$ \\
$\mathbf{1 9}$ & M. A R & 16. & 11.4 & 284.93 & 130.41 & $\mathbf{1 9 2 . 7 6}$ \\
$\mathbf{2 0}$ & M. A & 14. & 11.1 & 221.41 & 123.65 & $\mathbf{1 6 5 . 4 6}$ \\
$\mathbf{2 1}$ & M. S & 19. & 11.3 & 382.20 & 127.69 & $\mathbf{2 2 0 . 9 1}$ \\
$\mathbf{2 2}$ & SF & 16. & 11.2 & 263.08 & 127.23 & $\mathbf{1 8 2 . 9 6}$ \\
$\mathbf{2 3}$ & M. Z & 18. & 11.3 & 351.56 & 128.59 & $\mathbf{2 1 2 . 6 2}$ \\
$\mathbf{2 4}$ & S P & 17. & 11.2 & 304.15 & 125.44 & $\mathbf{1 9 5 . 3 2}$ \\
$\mathbf{2 5}$ & R H & 16. & 12.1 & 284.93 & 146.89 & $\mathbf{2 0 4 . 5 8}$ \\
\hline E & & $\mathbf{4 3 5}$ & $\mathbf{2 9 4 .}$ & $\mathbf{7 7 2 8 . 8}$ & $\mathbf{3 4 7 9 . 3}$ & $\mathbf{5 1 3 7 . 4}$
\end{tabular}

Setelah data IMT dan kelincahan menggiring bola terkumpul maka pada tahap ini peneliti akan memasukkan data sampel kedalam tabel kerja dengan ketentuannnya: $\mathrm{X}=$ Idex Masa Tubuh (IMT), Y = Kelincahan menggiring bola, $\mathrm{x}^{2}=$ kuadrat dari $\mathrm{X}, \mathrm{x} 2=$ kuadrat dari $\mathrm{Y}$ dan $\mathrm{x} . \mathrm{y}=$ hasil kali variabel $\mathrm{x}$ dan variabel $\mathrm{y}$. Dari seluruh angka yang tertera dalam tabel kerja tersebut dari masimg-masing variabel, selanjutnya jumlah angka-angka variable dimasukkan kedalam rumus koefesien produck moment, dengan rumus sebagai berikut:

$$
\operatorname{rxy}=\frac{\mathrm{N} \sum \mathrm{xy}-\left(\sum \mathrm{X}\right)\left(\sum \mathrm{Y}\right)}{\sqrt{\left\{\mathrm{N} \sum \mathrm{X}^{2}-\left(\sum \mathrm{X}\right)^{2} / \mathrm{N} \sum \mathrm{Y}^{2}-\left(\sum \mathrm{Y}\right)^{2}\right\}}}
$$

keterangan :

rxy $\quad=$ koefesien korelasi antara variabel $\mathrm{X}$ dan $\mathrm{Y} \mathrm{N}$

$=$ jumlah subjek penelitian

$\sum \mathrm{xy}=$ jumlah hasil penelitian tiap-tiapskor asli dari $\mathrm{x}$ dan $\mathrm{y}$ 
$\sum \mathrm{x} \quad=$ jumlah skor variabel $\mathrm{x}$

rxy $=\frac{N \sum x y-\left(\sum X\right)\left(\sum Y\right)}{\sqrt{\left\{N \sum X^{2}-\left(\sum X\right)^{2} / N \sum Y^{2}-\left(\sum Y\right)^{2}\right.}}$

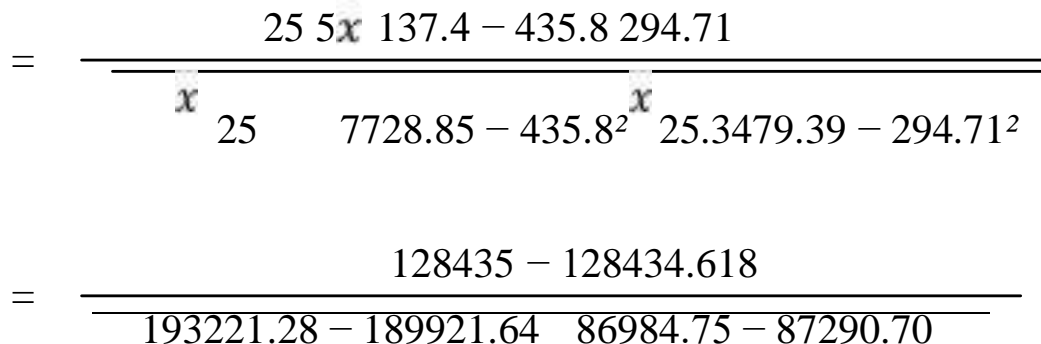

$=\frac{0.382}{3299.61-305.95}$

$=\frac{0.382}{\sqrt{1009515.67}}$

$=\frac{0.382}{1004.75}$

$r x y=3.801$

Setelah mendapatkan nilai r-hitung, diperoleh nilai sebesar 3.801 kemudian nilai rtabel dengan derajat kebebasan (db) $\mathrm{N}=25$ r-tabel sebesar 0,396, atau dengan kata lain $\mathrm{r}$ hitung yang diperoleh lebih besar dari angka batas penolakan hipotesis nihil (Ho) yang tercantum dalam tabel nilai " $r$ " kenyataan di atas yaitu $r$-hitung lebih besar dari r-tabel $(0.396$ $<3.801$ ), dengan demikian nilai r-hitung yang diperoleh dalam penelitian ini adalah signifikan Dari hasil penelitian menunjukkan bahwa nilai r-hitung diperoleh sebesar 3.801 sedangkan nilai r-tabel dengan taraf signifikan 5\% menunjukkan sebesar 0.396 hal ini berarti bahwa rhitung yang diperoleh lebih besar dari angka batas penolakan hipotesis nihil (Ho) yang tercantum dalam tabel product moment. Untuk menolak hipotesis nihil (Ho) diperlukan nilai rhitung sama atau lebih besar dari nilai r-tabel. Dari pembahasan diatas menunjukkan bahwa: Ada hubungan indek masa tubuh dengan kelincahan menggiring bola pada siswa putra ekstra kulikuler sepak bola siswa SMAN 1 Aikmel tahun 2017. Hal ini didasari atas pertimbangan bahwa Ho sengaja dipersiapkan untuk ditolak sedangkan $\mathrm{Ha}$ dipersiapkan untuk diterima (Danim dan Darwis,2005:171). Pernyaataan diatas menunjukkan bahwa indek masa tubuh 
sangat sangat berpengaruh bagi kelincahan siswa khsususnya dalam olahraga sepak bola. Selain memiliki teknik sepak bola yang baik, memiliki kecepatan dan juga kelincahan adalah hal yang penting untuk bisa menjadi pemain yang handal dalam tim. Tim dengan pemain handal akan memiliki kesempatan lebih besar untuk bisa memenangkan pertandingan. Beberapa pemain dalam tim harus memiliki kelincahan dan kecepatan yang sangat baik agar dapat membantu tim mencapai kemenangan seperti pemain yang berada di posisi penyerang atau sayap.

\section{Simpulan}

Berdasarkan hasil analisis data diperoleh nilai $r$ hitung lebih besar dari r-tabel (3.801> 0.396) dengan taraf signifikan 5\%. Untuk menolak (Ho) diperlukan nilai t-nilai (hitung sama atau lebih besar dari nilai $r$ tebel). Maka, dapat disimpulkan bahwa: Ada hubungan IMT dengan kelincahan menggiring bola pada siswa putra ekstra kulikuler sepak bola siswa SMAN 1 Aikmel tahun 2017. Sehubungan dengan hasil penelitian ini, peneliti mengajukan saran antara lain: Kepada pemain dan atlit agar menjaga indek masa tubuh karena rasio standar berat terhadap tinggi badan dapat berpengaruh terhadap kelincahan didalam lapangan. Kepada peneliti lain yang menggunakan hasil penelitian ini agar lebih mengembangkan ruang lingkup dan variabelnya demi kesempurnaan hasil peneltian kedepan.

\section{Daftar Pustaka}

Agus Salim. (2008). "Buku Pintar Sepakbola”. Bandung: Nuansa. Arikunto, S. (2012) Penelitian Tindakan Kelas. Jakarta: Bumi Aksara (2006). Prosedur Penelitian Suatu Pendekatan Praktek. Jakarta: Rineka Cipta.

Available from: URL: HIPERLINK http://www.who.int/cardiovascular disease/en/cvd atlas 15 burden stroke.pdf, diunduh pada Senin, 29 Maret 2017 jam 9.11PM.

Danim, Sudarwan. (2005). Menjadi Peneliti Kualitatif, Jakarta: Bumi Aksara. Depkes RI, (2007). Profil Kesehatan Indonesia Tahun 2006, Medan.

Luxbacker, Joseph A. (2008). Sepak bola. Edisi Kedua. Jakarta: PT Rajagrafindo Persada.

Maksum, Ali. 2009. Metode penelitian dalam olahraga. Surabaya: Fakultas Ilmu Keolahragaan. Universitas Negeri Surabaya.

Mielke Danny, (2007). Dasar-Dasar Sepak Bola. Cara Yang Lebih Baik Untuk Mempelajarinya. Pakar Raya, Bandung.

Muhajir. (2004). Pendidikan Jasmani Olahraga dan Kesehatan. Jilid 1. Jakarta: Erlangga.

Muhajir, M. (2007). Pendidikan Jasmani dan Kesehatan, Jakarta: Erlangga. Nurhasan. (2007). Tes dan pengukuran Dalam Pendidikan Jasmani: Prinsip Prinsip dan Penerapannya. Jakarta: Depdiknas.

Prastowo, Andi. (2011). Metode Penelitian Kualitatif dalam Perspektif Rancangan Penelitian. Yogyakarta: Ar-Ruzz Media.

Sukandar, Rumidi. 2002. "Metodologi Penelitian Petunjuk Praktis untuk Penelitian Pemula". Yogyakarta: UGM Press.

Robert Koger, (2007). Latihan Dasar Sepak Bola Remaja. Klaten. Macana Jaya Cemerlang. 
Scheunemann Timo, (2008). Dasar Sepak bola Modern Untuk Pemain Dan Pelatih. Percetakan Dioma. Malang.

Sucipto. Dkk. (2000). Sepak bola. Jakarta: Depdikbud Dirjen Dikti. Suharjana, (2008). Pendidikan Kebugaran Jasmani. Pedoman Kuliah. Yogyakarta. FIK UNY.

Suharsimi Arikunto. (2010). Prosedur Penelitian: Suatu Pendekatan Praktik. (Edisi Revisi). Jakarta: Rineka Cipta

Sugiyono. (2009). Metode Penelitian Bisnis (Pendekatan Kuantitatif, Kualitatif, dan R\&D). Bandung: Alfabeta.

(2013). Metode Penelitian Pendidikan Pendekatan Kuantitatif, Kualitatif, dan R\&D. Bandung: Alfabeta.

(2014) Metode Penelitian Kuantitatif Kualitatif dan R\&D. Bandung: Alfabeta.

WHO. (2007) Global Burden of Stroke. world health organization; 2007. 